Jurnal Keperawatan Silampari

Volume 1, Nomor 2, Juni 2018

e-ISSN: 2581-1975

p-ISSN: 2597-7482

DOI: https://doi.org/10.31539/jks.v1i2.9

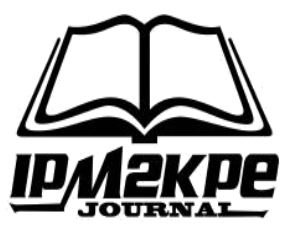

\title{
STIMULASI PERMAINAN PUZZLE BERPENGARUH TERHADAP PERKEMBANGAN SOSIAL DAN KEMANDIRIAN ANAK USIA PRASEKOLAH
}

\author{
Tunggul Sri Agus Setyaningsih ${ }^{1}$, Hesti Wahyuni² \\ Akademi Keperawatan, Rumah Sakit Dustira Cimahi ${ }^{1,2}$ \\ tunggul_sriagussetyaningsih@yahoo.com ${ }^{1}$
}

\begin{abstract}
ABSTRAK
Tujuan penelitian adalah menganalisis pengaruh pemberian stimulasi permainan puzzle terhadap perkembangan sosial dan kemandirian pada anak usia prasekolah. Metode Penelitian ini menggunakan metode penelitian kuantitatif dengan desain quasi eksperimental one group pre test-post test. Hasil penelitian dianalisis dengan menggunakan uji Wilcoxon terhadap status perkembangan anak sebelum dan sesudah intervensi yang didapatkan nilai signifikan 0,000 ( $p$-value $<0,05)$. Simpulan, terdapat pengaruh yang bermakna antara pemberian stimulasi puzzle terhadap perkembangan sosial dan kemandirian.
\end{abstract}

Kata kunci : Perkembangan Anak, Permainan Puzzle, Quasi Eksperimental

\begin{abstract}
The purpose of this study was to analyze the effect of providing puzzle game stimulation on social development and independence in preschool children. Method This study uses quantitative research methods with a quasi experimental one group pre-post test design. The results of the study were analyzed using the Wilcoxon test on the development status of children before and after the intervention which obtained a significant value of 0,000 ( $p$-value <0.05). Conclusion, there is a significant influence between providing puzzle stimulation on social development and independence.
\end{abstract}

Keywords: Child Development, Puzzle Games, Quasi Experimental 


\section{PENDAHULUAN}

Perkembangan anak yang optimal pada usia dini akan menjadi penentu bagi tahap-tahap perkembangan selanjutnya (Nugroho, 2009). Anak usia prasekolah yang merupakan bagian dari anak usia dini yang berada pada rentang usia lahir sampai 6 tahun dan fase ini merupakan usia emas (golden age) karena pada usia ini anak memiliki peranan penting untuk mengembangkan berbagai potensi (Depdiknas, 2006; Depkes, 2010). Stimulasi yang kurang pada anak dapat mengakibatkan gangguan tumbuh kembang yang akan mempengaruhi perilaku anakdikemudian hari (Attwood, 2002).

Dilihat dari proporsi penduduk Indonesia $40 \%$ dari total populasi terdiri atas anak dan remaja berusia 0-16 tahun dan sebanyak 13,5\% anak balita Indonesia merupakan kelompok usia berisiko tinggi mengalami gangguan perkembangan(Hamid, 2008). Berdasarkan data Ikatan Dokter Anak Indonesia (IDAI, 2013) diperkirakan 5-10\% anak mengalami keterlambatan perkembangan dan sekitar 1-3\% balita mengalami keterlambatan perkembangan umum (global developmental delay), namun angka kejadian keterlambatan perkembangan di Indonesia sampai saat ini belum ada data pasti, karena penelitian tentang hal ini belum banyak dilaporkan.

Christiari, Syamlan dan Kusuma (2013) menjelaskan bahwa skrining deteksi dini perkembangan anak pernah dilakukan oleh Depkes RI pada tahun 2003 di 30 provinsi di Indonesia dan dilaporkan 45,12\% bayi mengalami gangguan perkembangan. Cakupan deteksi dini tumbuh kembang anak prasekolah tingkat Provinsi Jawa Tengah pada tahun 2007 sebesar 35,66\% dengan kisaran antara yang terendah 3,82\% di Kabupaten Kebumen dan yang tertinggi 100\% di Kabupaten Kendal. Hasil cakupan di tahun 2008 sebesar 44,76\% meningkat bila dibandingkan dengan cakupan tahun 2007. Pusdatin Kemenkes RI (2008) menjelaskan dalam Profil Kesehatan Jawa Tengah bahwa cakupan tersebut masih jauh dibawah target tahun 2006 sebesar 75\%.

Berdasarkan studi pendahuluan yang dilakukan oleh peneliti pada bulan September 2015 di TK Aisyiyah dari hasil wawancara yang dilakukan pada kepala sekolah mengatakan bahwa anak berada di TK selama 30 jam dalam seminggu. Hasil skrining perkembangan yang dilakukan dengan menggunakan Kuesioner Praskrining Perkembangan (KPSP), didapatkan bahwa sosialisasi dan kemandirian menjadi aspek keterlambatan perkembangan anak paling banyak. Melihat kondisi tersebut diperlukan stimulasi sesuai dengan usia anak prasekolah yang dikenal dengan masa usia bermain. Salah satu alat permainan yang dapat digunakan untuk membantu stimulasi perkembangan anak adalah puzzle. Penelitian ini bertujuan untuk mengetahui pengaruh pemberian stimulasi permainan puzzle terhadap perkembangan sosial dan kemandirian pada anak usia prasekolah di TK Aisyiyah Petanahan.

\section{METODE PENELITIAN}

Penelitian ini merupakan penelitian kuantitatif dengan desainQuasi eksperimental one group pre test - post test. Sampel dalam penelitian ini adalah anak berusia 5 tahun (60 bulan) dengan status perkembangan meragukan pada aspek sosialisasi dan kemandirian yang berjumlah 17 orang dengan teknik purpossive sampling. Instrumen yang digunakan adalah puzzle dan Kuesioner Praskrining Perkembangan Anak (KPSP). Hasil penelitian dianalisis dengan menggunakan uji Wilcoxon. 


\section{HASIL PENELITIAN \\ Analisa Univariat \\ Karakteristik Responden Anak}

Tabel. 1

Distribusi Frekuensi Karakteristik Responden Anak di TK

Aisyiyah Petanahan pada Bulan November 2015

\begin{tabular}{ccc}
\hline Karakteristik Responden & Frekuensi (n) & Presentase (\%) \\
\hline Jenis Kelamin Anak & & \\
Laki-laki & 11 & $64,7 \%$ \\
Perempuan & 6 & $35,3 \%$ \\
\hline
\end{tabular}

Berdasarkan tabel 1 menunujukkan distribusi frekuensi responden berdasarkan jenis kelamin anak. Karakteristik jenis kelamin anak dari 17 responden mayoritas responden adalah laki-laki yaitu berjumlah 11 orang $(64,7 \%)$, sedangkan perempuan berjumlah 6 orang $(35,3 \%)$.

\section{Perkembangan Sosial dan Kemandirian Anak Sebelum dan Sesudah Intervensi}

Tabel. 2

Perbedaan Rerata Skor Perkembangan Sosial dan Kemandirian Anak

Sebelum Intervensi dan Sesudah Intervensi pada Bulan November 2015

\begin{tabular}{cccc}
\hline Variabel & Rata-rata & Standar Deviasi & $\begin{array}{c}\text { Minimal } \\
\text { Maksimal }\end{array}$ \\
\hline $\begin{array}{c}\text { Perkembangan Sosial dan Kemandirian Anak } \\
\text { Sebelum Intervensi (pre test score) }\end{array}$ & 1,47 & 0,717 & $0-2$ \\
\hline $\begin{array}{c}\text { Perkembangan Sosial dan Kemandirian Anak } \\
\text { Sesudah Intervensi (post test score) }\end{array}$ & 2,64 & 0,606 & $1-3$ \\
\hline
\end{tabular}

Berdasarkan tabel 2 menunjukkan perkembangan sosial dan kemandirian anak pada responden sebelum dan sesudah intervensi. Dari hasil tersebut didapatkan rata-rata perkembangan sosial dan kemandirian anak sebelum intervensi adalah 1,47 dengan standar deviasi 0,717 , sedangkan sesudah intervensi berupa pemberian stimulasi permainan puzzle pada perkembangan sosial dan kemandirian nilai rata-rata perkembangan sosial dan kemandirian anak meningkat menjadi 2,64 dengan nilai standar deviasi menurun menjadi 0,606.

\section{Analisa Bivariat}

Analisa bivariat pada penelitian ini dilakukan untuk menguji hipotesis mengenai pengaruh pemberian stimulasi permainan puzzle pada perkembangan sosial dan kemandirian. Pengujian hipotesis dilakukan dengan menganalisa perbedaan rerata status perkembangan sosial dan kemandirian pada anak prasekolah sebelum dan sesudah intervensi.

Uji Normalitas sebelum dilakukan analisis bivariat, dilakukan uji normalitas terlebih dahulu terhadap data yang telah diperoleh. Hasil uji normalitas akan menentukan analisis bivariat yang akan digunakan. Jika hasil uji normalitas sebaran data normal maka untuk analisis bivariat menggunakan uji tberpasangan, bila sebaran data tidak normal, uji yang digunakan adalah uji wilcoxon. Hasil uji normalitas yang didapatkan pada penelitian ini adalah sebagai berikut : 
Tabel. 3

Distribusi Hasil Uji Normalitas Data Bulan November 2015

\begin{tabular}{cccc}
\hline Variabel & Frekuensi (N) & \multicolumn{2}{c}{ Shapiro-Wilk } \\
\cline { 3 - 4 } & & $\mathrm{df}$ & Sig. \\
\hline $\begin{array}{c}\text { Perkembangan Sosial dan Kemandirian Anak } \\
\text { Sebelum Intervensi (pre test score) }\end{array}$ & 17 & 17 & 0,000 \\
\hline $\begin{array}{c}\text { Perkembangan Sosial dan Kemandirian Anak } \\
\text { Setelah Intervensi (post test score) }\end{array}$ & 17 & 17 & 0,001 \\
\hline
\end{tabular}

Tabel 3 menjelaskan hasil uji normalitas menggunakan shapiro- wilk karena jumlah responden $\leq 50$ orang (Dahlan, 2012). Hasil uji normalitas untuk nilai pre test perkembangan sosial dan kemandirian anakadalah 0,000 sedangkan untuk nilai post test adalah 0,001 . Hal ini menunjukan bahwa data pre test dan post test tersebut tidak terdistribusi normal ( $\mathrm{p}$-value $<0,05$ ), sehingga akan dilakukan transformasi data terlebih dahulu.

Pengaruh pemberian stimulasi permainan puzzle terhadap perkembangan sosial dan kemandirian terhadap perbedaan rerata skor pada pre test-post test.

Analisa bivariat yang digunakan dalam penelitian ini adalah uji non parametrik menggunakan uji wilcoxon. Hasil uji wilcoxon digunakan untuk mengetahui pengaruh intervensi berupa pemberian stimulasi permaian puzzle terhadap perkembangan sosial dan kemandirian anak. Hasil uji wilcoxon yang didapatkan pada penelitian ini adalah sebagai berikut:

Tabel. 4

Pengaruh Pemberian Stimulasi Permainan Puzzle terhadap Perbedaan Rerata Skor pada Pre Test-Posttest pada Bulan November 2015

\begin{tabular}{lcccc}
\hline \multicolumn{1}{c}{ Variabel } & $\begin{array}{c}\text { Frekuensi } \\
(\mathrm{N})\end{array}$ & $\begin{array}{l}\text { Rata- } \\
\text { rata }\end{array}$ & $\begin{array}{l}\text { Minimu } \\
\text { Maksimum }\end{array}$ & p- value \\
\cline { 1 - 4 } $\begin{array}{l}\text { Perkembangan Sosial dan Kemandirian Anak } \\
\text { Sebelum Intervensi (pre test score) }\end{array}$ & 17 & 1,47 & $0-2$ & \\
\cline { 1 - 3 } $\begin{array}{l}\text { Perkembangan Sosial dan Kemandirian Anak } \\
\text { Sesudah Intervensi (post test score) }\end{array}$ & 17 & 2,64 & $1-3$ & 0,00 \\
\hline
\end{tabular}

Berdasarkan tabel 4 menunjukkan rerata skor perkembangan sosial dan kemandirian anak dengan analisis uji wilcoxon dengan nilai $\alpha=0,05$ yaitu didapatkan nilai signifikan 0,000 ( $\mathrm{p}$-value $<0,05$ ). Secara statistik terdapat pengaruh bermakna stimulasi permainan puzzle yang diberikan terhadap nilai rerata perkembangan sosial dan kemandirian anak sebelum dengan sesudah intervensi.

\section{PEMBAHASAN}

Pada penelitian ini karakteristik responden anak adalah anak yang berusia 5 tahun (60 bulan) yang mengalami keterlambatan pada aspek sosisalisasi dan kemandirian dan dibagi berdasarkan jenis kelamin anak. Dari 17 responden mayoritas responden adalah laki-laki yaitu berjumlah 11 orang $(64,7 \%)$, sedangkan perempuan berjumlah 6 orang (35,3\%). Sejalan dengan hasil penelitian yang dilakukan oleh Tjanradjani et al (2012) tentang keluhan keterlambatan perkembangan umum (KPU) anak bahwa sebaran responden berdasarkan jenis kelamin didapatkan laki-laki (66\%) lebih banyak dibandingkan dengan perempuan (34\%). Hal ini relatif sama dengan penelitian lain yang menyatakan bahwa kebanyakan pasien KPU adalah laki-laki. 
Jenis kelamin sendiri merupakan salah satu faktor yang dapat mempengaruhi tumbuh kembang anak yang termasuk kedalam faktor dalam (internal), sehingga tumbuh kembang antara anak laki-laki dan perempuan cenderung akan berbeda (Depkes RI, 2010) namun masih diperlukan penelitian lebih lanjut untuk mengetahui hubungan antara jenis kelamin anak terhadap keterlambatan perkembangan anak.

Dari hasil penelitian menunjukkan bahwa rata-rata perkembangan sosial dan kemandirian anak sebelum intervensi adalah 1,47 dengan standar deviasi 0,717, sedangkan sesudah intervensi berupa pemberian stimulasi permainan puzzle pada perkembangan sosial dan kemandirian nilai rata-rata perkembangan sosial dan kemandirian anak meningkat menjadi 2,64 dengan nilai standar deviasi menurun menjadi 0,606 .

Perkembangan merupakan suatu proses yang terjadi secara simultan dengan pertumbuhan yang menghasilkan kualitas individu untuk berfungsi, yang dihasilkan melalui proses pematangan dan proses belajar dari lingkungannya (Supartini, 2004). Wong (2009) menjelaskan bahwa perkembangan sosialdan kemandirian anak prasekolah sudah dapat berhubungan dengan orang yang tidak dikenal dengan mudah dan mentoleransi perpisahan singkat dari orangtua dengan sedikit atau tanpa protes, merekamampu mengemukakan keinginan akan kemandirian dan melakukannya secara mandiri karena perkembangan fisik dan kognitifnya yang semakin meningkat, pada usia 4 sampai 5 tahun merekahanya memerlukan sedikit bantuan (jika perlu) untuk berpakaian, makan atau ke toilet. Menurut Depkes (2010) menjelaskan bahwa sosialisasi dan kemandirian merupakan aspek yang berhubungan dengan kemampuan mandiri anak (makan sendiri, membereskan mainan selesai bermain), berpisah dengan ibu atau pengasuh anak, bersosialisasi dan berinteraksi dengan lingkungannya dan sebagainya.

Pendidikan prasekolah membantu meletakkan dasar ke arah perkembangan sikap, intelektual, ketrampilan fisik dan motorik, sosial, moral, dan daya cipta yang diperlukan oleh anak- anak untuk menyesuaikan diri dengan lingkungannya, serta untuk pertumbuhan dan perkembangan tahap selanjutnya. Salah satu ciri pada usia ini adalah mulai meluasnya lingkungan sosial anak. Bila pada usia sebelumnya anak merasa cukup dengan lingkungan pergaulan dalam keluarga, maka pada usia prasekolah mulai merasakan adanya kebutuhan untuk memiliki teman bermain, serta memiliki aktivitas yang teratur di luar lingkungan rumah. Bagi anak-anak yang bersekolah di sebuah Taman Kanak-kanak (TK) memiliki kebutuhan akan adanya seorang figur pendidik, memiliki kebutuhan untuk beraktivitas dalam situasi dan kondisi yang bervariasi, tempat anak-anak belajar mengembangkan potensi yang ada pada dirinya, mengembangkan kemandirian dan memperoleh pengalaman yang lain yaitu tunduk pada otoritas selain orang tuanya. Pengalaman inilah yang membuat anak menjadi perlunya melihat persoalan dari sudut pandang orang lain. Kemampuan inilah yang disebut sebagai kemampuan kognisi sosial yang pada tahap perkembangan seterusnya akan menjadi dasar anak untuk dapat bersosialisasi dengan baik. TK sebagai area penting jembatan antara keluarga dan sekolah formal bagi anak-anak adalah lebih jauh dari sekedar menyediakan tempat bersosialisasi, tetapi juga proses internalisasi nilai dan perilaku yang diterima di masyarakat termasuk kemandirian.

Hasil penelitian ini didapatkan dari total 117 anak yang dilakukan screening perkembangan anak didapatkan 29 anak (24,5\%) dengan status perkembangan meragukan. Dari 29 anak dengan perkembanganmeragukan tersebut didapatkan 23 anak dengan keterlambatan pada aspek sosialisasi dan kemandirian, dan 6 anak dengan 
keterlambatanpada aspek perkembangan lainnya (pada aspek bicara bahasa dan gerakhalus). Ini menandakan bahwa masih adanya keterlambatan perkembangan pada anak prasekolah (5 tahun) terutama pada aspek sosialisasi dan kemandirian.

Berdasarkan hasil diatas pada kemampuan sosialisasi dan kemandirian sejalan dengan teori yang dijelaskan oleh Novita, Windya, (2007) bahwa penilaian perkembangan anak untuk mendeteksi keterlambatan sedini mungkin penting dilakukan karena gangguan kemampuan belajar cenderung muncul sebagai akibat perkembangan terlambat, tetapi belum tentu sebaliknya. Jamaris (2006) menjelaskan bahwa pada anak usia prasekolah mulai dapat memecahkan masalah, mulai belajar mengembangkan keterampilan mendengar untuk mempermudah berinteraksi dengan lingkungan, proses berpikir sesuai dengan yang ditangkap panca indera. Menurut Hidayat (2011) menjelaskan proses sosialisasi dapat terjadi melalui permainan, misalnya pada saat anak akan merasakan kesenangan terhadap kehadiran orang lain dan merasakan ada teman yang dunianya sama. Pada usia prasekolah anak sudah mulai menyadari keberadaan teman sebaya, sehingga diharapkan anak mampu melakukan sosialisasi dengan teman dan orang lain.

Usia prasekolah merupakan masa kritis dalam perkembangan siklus hidup seseorang. Menurut Erikson (1950) dalam Soetjiningsih, C. H. (2012) anak usia prasekolah berada pada tahap initiative vs guilt yang sedang berkembang ke arah industry vs inferiority. Pada tahap ini anak mengalami perkembangan yang positif dalam kreativitas, memiliki banyak ide dan imajinasi, berani mencoba, berani mengambil risiko, dan mudah bergaul. Sudaryanti (2012) menyatakan bahwa anak usia dini memiliki perkembangan fisik, motorik, intelektual, dan sosial yang sangat pesat dan menjadi landasan awal bagi tumbuh dan kembang anak. Hal ini menunjukkan betapa pentingnya masa pertumbuhan dan perkembangan anak usia dini yang tentunya membutuhkan stimulasi yang baik dari lingkungan di sekitarnya. Apabila masa usia dini anak tidak diberikan pengasuhan yang baik, maka dimungkinkan akan terjadi permasalahan pada perkembangan anak di masa mendatang.

Perkembangan sosial merupakan perkembangan tingkah laku pada anak yang diminta untuk menyesuaikan diri dengan aturan yang berlaku dalam lingkungan masyarakat. Dengan kata lain, perkembangan sosial merupakan proses belajar anak dalam menyesuaikan diri dengan norma, moral dan tradisi dalam sebuah kelompok (Yahro, 2009). Piaget menunjukkan adanya sifat egosentris yang tinggi pada anak karena anak belum dapat memahami perbedaan perspektif pikiran orang lain (Suyanto, 2005). Pada tahapan ini anak hanya mementingkan dirinya sendiri dan belum mampu bersosialisasi secara baik dengan orang lain. Anak belum mengerti bahwa lingkungan memiliki cara pandang yang berbeda dengan dirinya (Suyanto, 2005). Anak masih melakukan segala sesuatu demi dirinya sendiri bukan untuk orang lain.

Awal perkembangan sosial pada anak tumbuh dari hubungan anak dengan orang tua atau pengasuh dirumah terutama anggota keluarganya. Anak mulai bermain bersama orang lain yaitu keluarganya. Tanpa disadari anak mulai belajar berinteraksi dengan orang diluar dirinya sendiri yaitu dengan orang-orang disekitarnya. Interaksi sosial kemudian diperluas, tidak hanya dengan keluarga dalam rumah namun mulai berinteraksi dengan tetangga dan tahapan selanjutnya ke sekolah.

Perkembangan sosial anak sangat dipengaruhi oleh proses perlakuan atau bimbingan orang tua terhadap anak dalam mengenalkan berbagai aspek kehidupan sosial atau norma dalam masyarakat. Proses ini biasanya disebut dengan sosialisasi. Tingkah laku sosialisasi adalah sesuatu yang dipelajari, bukan sekedar hasil dari 
kematangan. Perkembangan sosial anak diperoleh selain dari proses kematangan juga melalui kesempatan belajar dari respons terhadap tingkah laku.

Perkembangan sosial mulai agak komplek ketika anak menginjak usia 4 tahun anak mulai memasuki ranah pendidikan yang paling dasar yaitu taman kanak-kanak (Rahman, 2002). Pada masa ini anak belajar bersama teman-teman diluar rumah. Anak sudah mulai bermain bersama teman sebaya (cooperative play). Vygotsky dan Bandura menyebutnya dengan teori belajar sosial melalui perkembangan kognitifnya. Anak usia TK (4-6 tahun) perkembangan sosial sudah mulai berjalan. Hal ini tampak dari kemampuan mereka dalam melakukan kegiatan secara berkelompok. Kegiatan bersama berbentuk seperti sebuah permainan. Tanda-tanda perkembangan pada tahap ini adalah anak mulai mengetahui aturan-aturan, baik di lingkungan keluarga maupun dalam lingkungan bermain, sedikit demi sedikit anak sudah mulai tunduk pada peraturan, anak mulai menyadari hak atau kepentingan orang lain, dan anak mulai dapat bermain bersama anak-anak lain, atau teman sebaya (peer group). Dari sisi sosial emosional, kegiatan bermain dalam melatih anak dalam memahami perasaan teman lainnya. Konflik dalam interaksi keduanya akan membantu anak dalam memahami bahwa orang selain dirinya yaitu temannya memiliki cara pandang yang berbeda dari dirinya.

Begitu pentingnya perkembangan sosial hingga Sri Esti (Yahro, 2009) mengatakan bahwa anak yang kurang popular adalah anak yang kurang memiliki keterampilan sosial. Perkembangan sosial dapat dipetakan dalam beberapa aspek. Kostelnik, Soderman \& Waren (Yahro, 2009) menyebutkan bahwa perkembangan sosial meliputi komperensi sosial dan tanggung jawab sosial. Kompetensi sosial menggambarkan keefektifan kemampuan anak dalam beradaptasi dengan lingkungan sosialnya, misalnya mau bergantian dengan teman lainnya dalam sebuah permainan. Tanggung jawab sosial menunjukkan komitmen anak terhadap tugasnya, menghargai perbedaan individual, memperhatikan lingkungannya dan mampu menjalankan fungsinya. Perkembangan sosial anak diperoleh dari kematangan dan kesempatan belajar dari berbagai respons lingkungan terhadap anak. Perkembangan sosial yang optimal diperoleh dari respons sosial yang sehat dan kesempatan yang diberikan kepada anak untuk mengembangkan konsep diri yang positif. Melalui kegiatan bermain, anak dapat mengembangkan minat dan sikapnya terhadap orang lain dan sebaliknya aktivitas yang terlalu banyak didominasi oleh guru akan menghambat perkembangan sosial emosi anak.

Kemandirian merupakan kemampuan untuk mengelola semua milik kita, mengelola waktu, berjalan dan berfikir secara mandiri, disertai kemampuan untuk mengambil resiko dan memecahkan masalah (Depkes, 2010). Menurut Erikson (dalam Deswita, 2011) menyatakan kemandirian merupakan usaha untuk melepaskan diri dari orangtua dengan maksud untuk menemukan dirinya melalui proses mencari identitas ego, yakni merupakan perkembangan kearah individualitas yang mantap dan berdiri sendiri. Kemandirian biasanya ditandai dengan kemampuan menentukkan nasib sendiri, kreatif dan inisiatif, mengatur tingkah laku, bertanggungjawab, mampu menahan diri, membuat keputusan keputusan sendiri, serta mampu mengatasi masalah tanpa ada pengaruh dari orang lain. Kemandirian meruapakan suatu sikap otonomi dimana diaman peserta didik secara relative bebas dari pengaruh penilaian, pendapatan, dan keyakinan orang lain.Melalui bermain dan berkomunikasi yang dijadwalkan sebagai program untuk memandirikan anak mengenai hal-hal yang telah dilakukan apabila berbuat salah anak tidak jera tetapi anak akan terus berusaha untuk lebih baik, mencari solusi belajar 
dari kesalahan, sehingga muncul rasa percaya diri dan tumbuhnya kemandirian anak karena pada kenyataannya disamping anak dalam keluarga, ia juga hidup di sekolah.

Yamin dan Sabri (2013) menyampaikan aspek kemandirian meliputi kemandirian sosial emosi, kemandirian fisik, dan kemandirian intelektual. Dalam penelitian Ghaye dan Pascall mengidentifikasikan tiga kegiatan berbeda dalam mengembangkan kemandirian sosial anak. Tiga kegiatan tersebut diantaranya pemisahan, transisi dan kerjasama. Pemisahan diartikan sebagai proses mendidik anak untuk lepas dari ketergantungan terhadap orangtua dan dewasa. Transisi merupakan proses yang dialami anak ketika anak berpindah ke lingkungan lainnya. Kerjasama dalam hal ini adalah kegiatan anak dalam suatu kelompok, dalam bekerjasama anak diharapkan dapat mengelola emosinya. Jika emosi terjaga maka hubungan sosial dengan teman ataupun dengan orang lain terjaga.

Anak usia dini memegang peranan sangat penting karena perkembangan otak manusia mengalami lompatan dan perkembangan yang sangat pesat yaitu $80 \%$, selebihnya berkembang sampai usia 18 tahun, oleh karena itu untuk mengoptimalkan perkembangan anak perlu diberikan stimulasi yang tepat pada semua aspek perkembangan (Gardner dalam Mulyasa, 2012).

Anak usia prasekolah memerlukan stimulasi yang tepat, salah satunya melalui kegiatan pembelajaran yang mampu mengembangkan pertumbuhan dan perkembangan anak secara menyeluruh. Perkembangan sosial dan kemandirian merupakan perkembangan yang berhubungan dengan interaksi orang tua, dan teman sebaya. Kemampuan yang dimiliki anak pada masa prasekolah diharapkan mampu mengantarkan anak untuk memasuki jenjang pendidikan selanjutnya dan mempersiapkan anak untuk menjalani kehidupan yang akan datang. Kemandirian yang diajarkan pada anak sejak dini akan membuatnya dapat mengatur waktu kegiatannya sendiri dan membuat anak terbiasa menolong orang lain serta lebih bisa menghargai orang lain.

Stimulasi perkembangan yang dilakukan pada penelitian ini adalah pada satu aspek perkembangan yaitu aspek sosialisasi dan kemandirian. Iswidharmanjaya \& Sukamti (2007) memaparkan salah satu penyebab anak takutbersekolah adalah karena adanya masalah kemandirian. Masalah belajar pada anak dapat mengakibatkan keterlambatan perkembangan yang spesifik akan mempengaruhi perilaku sosial anakyang tidak lazim (Attwood, 2002). Masalah pada kemandirian yang akan berdampak anak menjadi ragu-ragu untuk mengembangkan kreativitasnya, dan ini akan membuat anak tidak berani membuat keputusan (decission making) dalam kehidupannya sehari-hari (Novita, 2007). Memperhatikan hal tersebut, sangat diperlukan tata laksana yang baik dan efisien yang mudah dilakukan oleh guru dan orang tua anak untuk mengatasi keterlambatan perkembangan anak sebagai upaya pencegahan terhadap keterlambatan perkembangan anak lebih lanjut.

Kegiatan stimulasi, deteksi dan intervensi dini penyimpangan tumbuh kembang yang menyeluruh dan terkoordinasi diselenggarakan dalam bentuk kemitraan atau kerjasama antara keluarga, dengan tenaga profesional (kesehatan, pendidikan dan sosial) akan meningkatkan tumbuh kembang anak usia dini dan kesiapan memasuki jenjang pendidikan formal. Stimulasi memiliki peran penting bagi perkembangan anak. Anak yang banyak mendapat stimulasi akan lebih cepat berkembang daripada anak yang kurang atau bahkan tidak mendapatkan stimulasi (Depkes, 2010; Soetjiningsih, 2012). Menurutnya stimulasi juga berfungsi sebagai penguat (reinforcement) bagi anak. Memberikan stimulasi yang berulang dan terus menerus, rutin, dan intensif pada setiap 
aspek perkembangan anak berarti telah memberikan kesempatan pada anak untuk tumbuh dan berkembang secara optimal (Jafri, Ovari, 2015).

Stimulasi juga berperan bagi kemajuan perkembangan otak anak. Stimulasi dan pengalaman sensori yang diterima anak akan meningkatkan pembentukan hubungan antar sel-sel otak (sinapsis), tetapi hubungan ini tidak permanen (Irmawati, et al 2012). Paparan berbagai macam stimulasi baik stimulasi suara, stimulasi penglihatan, maupun stimulasi dari indera yang lain, serta keadaan lingkungan yang baik, dibutuhkan untuk membentuk hubungan sel-sel di otak ini (Mustard, 2010). Berk (2012) menjelaskan stimulasi akan menentukan sel otak (neuron) yang akan terus membentuk sinapsis baru dan yang akan mengalami pemangkasan sinaptik (synaptic pruning).

Andriana (2011) mengatakan bahwa perkembangan memerlukan rangsangan atau stimulasi, khususnya dalam keluarga, misalnya penyediaan mainan, sosialisasi anak, serta keterlibatan ibu dan anggota keluarga lain terhadap kegiatan anak. Orang tua dan keluarga diharapkan dapat memantau pertumbuhan dan perkembangan anaknya, agar dapat dilakukan intervensi dini bila anak mengalami kelainan atau gangguan (Depkes, 2010).

Anak usia prasekolah memerlukan stimulasi yang tepat, salah satunya melalui kegiatan pembelajaran yang mampu mengembangkan pertumbuhan dan perkembangan anak secara menyeluruh. Penguasaan kemampuan yang dimiliki anak pada masa pra sekolah diharapkan mampu mengantarkan anak untuk memasuki jenjang pendidikan selanjutnya dan mempersiapkan anak untuk menjalani kehidupan yang akan datang (Rasyid, 2009). Seiring berkembangnya keterampilan yang telah dikuasai oleh anak, diharapkan anak-anak dapat belajar mandiri dengan merawat dirinya sendiri, dalam memenuhi kebutuhannya, seperti melepas dan mengenakan pakaian, buang air kecil, ataupun memakai kaos kaki dan sepatunya sendiri tanpa bantuan orangtua maupun pengasuhnya (Sukamti, 2007).

Permainan adalah stimulasi yang sangat tepat bagi anak. Aspek perkembangan anak dapat ditumbuhkan secara optimal dan maksimal melalui kegiatan bermain. Bermain pada usia prasekolah telah terbukti mampu meningkatkan perkembangan mental, kecerdasan, daya pikir anak terangsang untuk mendayagunakan aspek emosional, sosial, serta fisiknya (Andriana, 2011). Permainan merupakan kegiatan bagi anak yang secara kontinu mempraktikan proses hidup yang rumit dan penuh stress, komunikasi, dan mencapai hubungan yang memuaskan dengan orang lain (Wong, 2009). Hal tersebut merupakan unsur yang penting untuk perkembangan anak baik fisik, emosi, mental, intelektual, kreativitas dan sosial (Depkes, 2010; Goldstein, 2012). Anak yang mendapat kesempatan cukup untuk bermain akan menjadi orang dewasa yg mudah berteman, kreatif, dan cerdas, bila dibandingkan dengan mereka yang masa kecilnya kurang mendapat kesempatan bermain (Soetjiningsih, 2012).

Masa prasekolah sebagai masa bermain, hampir seluruh kegiatan pada usia prasekolah perlu melibatkan unsur bermain melalui kegiatan bermain, anak belajar mengembangkan kemampuan sosialnya sehingga diharapkan munculnya emosi dan perilaku yang tepat sesuai dengan konteks yang dihadapi dan diterima oleh semua norma sosialnya. Kesadaran akan dunia lain disekitarnya mulai membuat anak menyesuaikan ikut masuk dalam pergaulan teman sebayanya. Perkembangan perilaku sosial anak ditandai dengan adanya minat terhadap aktivitas teman-teman dan meningkatkan keinginan yang kuat untuk diterima sebagai anggota suatu kelompok, dan tidak puas bila tidak bersama teman-temannya. Anak tidak lagi puas bermain sendiri dirumah atau dengan saudara-saudara kandung atau melakukan kegiatan dengan 
anggota-anggota keluarga, anak ingin bersama teman-temannya dan akan merasa kesepian serta tidak puas bila tidak bersama teman-temannya. Dua atau tiga teman tidaklah cukup baginya. Anak ingin bersama dengan kelompoknya, karena hanya dengan demikian terdapat cukup teman untuk bermain dan berolahraga, dan dapat memberikan kegembiraan. Sejak anak masuk sekolah sampai masa puber, keinginan untuk bersama dan untuk diterima kelompok menjadi semakin kuat. Hal ini, berlaku baik untuk anak laki-laki maupun anak perempuan (Mayar, 2013).

Penelitian yang dilakukan Liberman (1977, dalam Jamaris, 2006) bermain aktif yang terjadi di anak prasekolah secara signifikan berhubungan dengan tingginya skor dalam divergent thinking (kemampuan untuk berpikir berbeda) anak tersebut. Brunner (1972, dalam Jamaris, 2006) mengemukakan bahwa bermain mendorong anak melakukan berbagai kegiatan dalam memecahkan berbagai masalah melalui penemuan. Menurut teori dari Goldstein (2003) bermain peran menjadi koordinasi secara sosial, meningkatkan lama bermain dan bahasa yang lebih komplek.

Aspek perkembangan pada anak prasekolah didapatkan kriteria meragukan sangatlah banyak sehingga diperlukan intervensi dengan menggunakan alat permainan yang dapat menstimulasi perkembangan anak yaitu puzzle dengan harapanagar anak dapat beradaptasi sesuai dengan tahap perkembangan dan mengalami peningkatan pada kriteria normal. Jika dideteksi diperoleh keterlambatan (meragukan) dan penyimpangan pada perkembangan anak maka perlu diperinci jenis keterlambatan perkembangan sehingga dapat dikoreksi jenis perkembangan anak yang mengalami keterlambatan (Depkes, 2010). Menurut Havighurst (dalam Monks dkk, 2001, dalam Soetjiningsih, 2012) tugas perkembangan anak usia prasekolah meliputi pencapaian stabilitas fisiologis, belajar berbicara, berbahasa, belajar mengenai realitas sosial dan realitas fisik.

Pemberian stimulasi puzzle pada penelitian ini dilakukan selama 2 minggu. Hal ini mengikuti tata laksana Depkes RI (2010) tentang intervensi dini pada anak dengan perkembangan meragukan dapat dilakukan dengan memberikan stimulasi positif terarah sesuai dengan aspek keterlambatan perkembangan yang dialami yang dilakukan selama 2 minggu dan selanjutnya dievaluasi kembali dengan melakukan pemeriksaan perkembangan menggunakan KPSP. Stimulasi dilakukan setiap hari dengan durasi minimal 15 menit. Penelitian yang serupa oleh Susanty, Fadlyana, \& Nataprawira (2014) tentang manfaat intervensi dini anak usia 6-12 bulan dengan kecurigaan penyimpangan perkembangan dengan intervensi disarankan tiga kali sehari selama 1530 menit. Durasi tersebut cukup efektif sebagai intervensi untuk mengatasi keterlambatan perkembangan.

Pendapat Sunarti (2007) dalam penelitiannya selama 2 minggu dengan pemberian intervensi stimulasi alat permainan edukatif kepada anak prasekolah berlangsung selama 3-4 jam sehari memberikan pengaruh pada aspek perkembangan. Penelitian Mbae (2011) bahwa permainan puzzle dapat dilakukan secara bersama-sama dengan membagi 3 kelompok anak. Menurut Oguzkan \& Avci (2000, dalam Aral, 2012), sementara anak-anak menyelesaikan puzzle individual mereka mendapatkan beberapa keterampilan seperti melakukan aktivitas selama waktu tertentu, berbagi, kerjasama, menunggu giliran mereka, mematuhi aturan, konsentrasi, kepercayaan diri, pengaturan diri, rasa hormat untuk orang lain dan keterampilan mendengarkan. Permainan puzzle yang dilakukan secara berkelompok membantu anak dalam mengembangkan kemampuan bersosialisasi melalui kerjasama satu sama lain dan usaha anak untuk menyelesaikan tugas permainan puzzle sendiri akan membantu anak mengembangkan 
kemampuan kemandirian dalam menyelesaikan masalah. Menurut Sunarti (2005) permainan puzzle mempunyai tujuan mengenalkan anak beberapa strategi sederhana dalam menyelesaikan masalah, melatih kecepatan, kecermatan, dan ketelitin dalam menyelesaikan masalah, dan menanamkan sikap pantang menyerah dalam menghadapi masalah.

Penerapan menggunakan media puzzle dalam proses pembelajaran akan menstimulus anak untuk ikut aktif dalam pembelajaran. Adapun manfaat puzzle menurut Hamalik (2001) dapat meningkatkan perhatian anak dalam proses pembelajaran, suasana kelas menjadi aktif, dan menumbuhkan pemikiran yang teratur melalui gambar. Media puzzle juga dapat menstimulus anak lebih aktif mengikuti pembelajaran, warna dan potongan gambar yang bervariasi, memudahkan dalam menyampaikan materi.

Permainan puzzle bisa memberikan kesempatan belajar yang banyak kepada anak. Memainkan puzzle bersama-sama dapat merekatkan hubungan antara orang tua dan anak. Permainan puzzle memberikan tantangan tersendiri untuk anak disaat anak berada dalam kondisi bingung sebagai orang tua dapat menyemangati anak agar tidak patah semangat. Semangat yang diperoleh anak dapat menumbuhkan rasa percaya diri dan merasa mampu menyelesaikan permainan puzzle tersebut. Rasa percaya diri dapat menambah rasa aman kepada anak sehingga anak akan lebih aktif berpartisipasi dalam berbagai kegiatan lainnya. Yulianty (2011) menjelaskan kecerdasan otak anak akan terlatih karena permainan puzzle yang melatih sel-sel otak untuk memecahkan masalah. Mencoba beberapa cara memasangkan kepingan berupa potongan-potongan gambar maka anak dilatih berpikir kreatif. Memadukan atau memasangkan kepingan puzzle membantu anak memahami logika sebab akibat dari masalah dan gagasan bahwa objek yang utuh sebenarnya tersusun dai bagian-bagian yang kecil. Permainan puzzle melatih koordinasi tangan dan mata anak dikarenakan anak harus mencocokan keping-keping puzzle dan menyusunnya menjadi satu gambar utuh, membantu anak mengenal bentuk dan merupakan langkah penting menuju pengembangan keterampilan membaca. Aktivitas permainan puzzle, kesabaran akan terlatih karena saat bermain puzzle di butuhkan kesabaran dalam menyelesaikan permasalahan. Permainan puzzle memberikan pengetahuan kepada anak-anak untuk mengenal warna dan bentuk. Anak juga akan belajar konsep dasar binatang, alam sekitar, jenis-jenis benda, anatomi tubuh manusia, alphabet dan lain-lain. Di usia prasekolah perhatian anak terhadap ciri fisik objek (bentuk, warna, tekstur, dan lainnya) semakin detail. Pengetahuan diperoleh dari cara ini lebih mengesankan bagi anak dibanding dengan pengetahuan yang dihafalkan.

Menurut Montessory (dalam Mahardikha, 2013) menciptakan alat permainan edukatif yang memudahkan anak untuk mengingat konsep-konsep yang akan dipelajari tanpa perlu bimbingan sehingga memungkinkan anak dapat bekerja secara mandiri. Alat permainan edukatif ciptaannya banyak disesuaikan dengan kebutuhan anak usia prasekolah di Indonesia yaitu puzzle.

Hasil penelitian ini juga sependapat dengan penelitian lain yang dilakukan Aral (2012 \& 2011) tentang penggunaan puzzle yang diberikan pada area perkembangan anak prasekolah selama 2 hari dalam seminggu dan setiap sesi sehari diberikan sekitar 60 menit dan 45 menit selama 5 minggu, ditemukan perbedaan yang antara anak kelompok kontrol dan eksperimen pada skor pra dan post test sub skala The Brigance Early Development Inventory II signifikan ( $<<0.05)$. Efek puzzle terhadap perkembangan anak berdasarkan penilaian orang tua anak memiliki hasil yang sama. Penelitian Tekin dan Sezer (2010) selama 10 minggu pelatihan terapi bermain dalam 
konseling memberikan hasil yang positif dan menyimpulkan bahwa tahun awal telah diindikasikan sebagai masa hidup yang paling penting bagi perkembangan kognitif dan sosio emosional.

Wardhani (2012) bahwa permainan puzzle yang dilakukan dengan metode cooperative play dapat meningkatkan kemampuan sosialisasi pada anak dengan retradasi mental. Penelitian lain dari Kusumawati (2013), menyatakan bahwa penerapan media puzzle pada anak TK dengan jumlah 10 orang dapat meningkatkan media kognitif. Penelitian Sari (2006 \& 2007) alat permainan edukatif adalah alat permainan yang dapat mengoptimalkan perkembangan anak yang disesuaikan dengan usia dan tingkat perkembangan anak.

Setiap anak pasti akan mengalami perkembangan, namun sesuai dengan prinsip perkembangan anak adalah setiap anak memiliki kecepatan (tempo) dan kualitas perkembangan yang berbeda (Sain, 2013) karena itu kemajuan perkembangan pada anak terkadang tidak muncul sendiri tetapi perlu di stimulasi sebagai upaya pembelajaran dan latihan pada anak. Menjelaskan lebih lanjut, perkembangan juga ditunjukkan dengan perubahan yang bersifat sistematis, progresif dan berkesinambungan. Perkembangan akan dicapai karena adanya proses belajar, sehingga anak memperoleh pengalaman baru dan menimbulkan perilaku baru. Idealnya pada anak terjadi suatu proses pembelajaran yang intensif dengan memberikan stimulasi positif sehingga bisa mengoptimalkan perkembangan anak (Silawati, 2010).

Penelitian ini sejalan dengan penelitian yang dilakukan oleh Susanty, Fadlyana, dan Nataprawira (2014), didapatkan hasil setelah intervensi kecurigaan penyimpangan perkembangan turun menjadi 12/32 setelah 2 minggu, dan 4/32 pada akhir intervensi $(\mathrm{p}<0,001)$. Sejalan dengan hasil penelitian Irmawati et al (2012) yang menunjukan bahwa evaluasi perkembangan setelah 3 bulan mengalami perbaikan baik pada kelompok stimulasi maupun pada kelompok kontrol. Penelitian lain yang dilakukan oleh Gultiano \& King (2006) di Philipina membuktikan bahwa terjadi peningkatan perkembangan psikososial sebesar $6-11 \%$ pada anak usia 0-4 tahun yang dilakukan stimulasi selama 2 tahun.

Pertumbuhan masa anak prasekolah berlangsung dengan stabil. Terjadi perkembangan dengan aktivitas jasmani yang bertambah dan meningkatnya ketrampilan dan proses berfikir. Memasuki masa prasekolah, anak mulai menunjukkan keinginannya, seiring dengan pertumbuhan dan perkembangannya. Pada masa ini, selain lingkungan didalam rumah maka lingkungan diluar rumah mulai diperkenalkan. Anak mulai senang bermain diluar rumah. Anak mulai berteman, bahkan banyak keluarga yang menghabiskan sebagian besar waktu anak bermain diluar rumah dengan cara membawa anak ke taman- taman bermain, taman- taman kota, atau ke tempat tempat yang menyediakan fasilitas permainan untuk anak. Sepatutnya lingkunganlingkungan tersebut menciptakan suasana bermain yang bersahabat untuk anak (child friendly environment). Semakin banyaktaman bermain dibangun untuk anak, semakin baik untuk menunjang kebutuhan anak. Pada masa ini anak dipersiapkan untuk sekolah, untuk itu panca indra dan sistem reseptor penerima rangsangan serta proses memori harus sudah siap sehingga anak mampu belajar pada masa ini dengan cara bermain (Depkes, 2010). Menurut Harlock (2007) secara sosial, anak mampu menjalin kontak sosial dengan orang-orang yang ada diluar rumah, sehingga anak mempunyai minat yang lebih untuk bermain dengan temannya, orang-orang dewasa, dan saudara kandung didalam keluarga. 
Hasil penelitian ini didapatkan adanya pengaruh pemberian stimulasi permainan puzzle terhadap nilai rerata status perkembangan anak. Rata-rata peningkatan nilai perkembangan sosial dan kemandirian anaksebelum intervensi yaitu 1,47 dan setelah intervensi adalah 2,64. Darikedua rata-rata proporsi hasil pengukuran mengalami perbedaan sebesar1,17 artinya perkembangan sosial dan kemandirian anak mengalami peningkatan. Berdasarkan hasil uji statistik didapatkan nilai signifikan 0,000 (p-value < 0,05), sehingga dapat disimpulkan bahwa terdapat pengaruh yang bermakna antara pemberian stimulasi permainan puzzle terhadap peningkatan perkembangan sosial dan kemandirian anakyang mengalami keterlambatan (status perkembangan meragukan). Hasil penelitian ini sesuai dengan hasil hipotesis penelitian yaitu terdapat pengaruh pemberian stimulasi permainan puzzle terhadap status perkembangan anak.

\section{SIMPULAN}

Karakteristik responden anak mayoritas anak berjenis kelamin laki-laki yaitu berjumlah 11 orang (64,7\%). Perkembangan sosial dan kemandirian anak sebelum dilakukan intervensi berupa pemberian stimulasi puzzle terhadap aspek sosialisasi dan kemandirian didapatkan rata-rata yaitu 1,47 dengan standar deviasi 0,717. Perkembangan sosial dan kemandirian anak sesudah intervensi didapatkan nilai ratarata menjadi 2,64 dengan standar deviasi 0,606.

Ada pengaruh bermakna stimulasi pemberian permainan puzzle terhadap nilai rerata perkembangan sosial dan kemandirian anak sebelum dengan sesudah intervensi yaitu didapatkan nilai significancy 0,000 ( $\mathrm{p}$-value $<0,05$ ).

\section{SARAN}

Penelitian ini diharapkan dapat memperkaya informasi bagi keperawatan terutama keperawatan anak, sebagai acuan dalam tata laksana perkembangan anak dengan status meragukan yaitu pemberian stimulasi yang dilakukan oleh perawat, guru, dan orang tua anak dengan pendekatan family center care dalam asuhan keperawatan. 


\section{DAFTAR PUSTAKA}

Andriana, D. (2011). Tumbuh Kembang dan Terapi Bermain pada Anak. Jakarta: Salemba Medika

Aral, N. (2011). An Investigation of the Effect of Puzzles as Instructional Materials on Preschoolers' Developmental Areas According to Their Mothers' Evaluation. Ankara University: Barcelona European Academic Conference

Aral, N. (2012). An Investigation of the Effect of Puzzle Design on Children's Development Areas. Ankara University: Procedia-Social and Behavioral Sciences

Attwood, Tony. (2002). Asperger's Syndrome: a Guide for Parents and Professionals. London, Philadelphia: Jessica Kingsley Publishers

Berk, L. E. (2012). Foundations of Development. Dalam: Berk LE, editor. Simple Chapter: Child Development, Edisi ke-8. Illinois: Pearson Publishing

Christiari, A. Y., Syamlan, R., Kusuma, I. F. (2013). Hubungan Pengetahuan Ibu tentang Stimulasi Dini dengan Perkembangan Motorik pada Anak Usia 6-24 Bulan di Kecamatan Mayang Kabupaten Jember. Jurnal Pustaka Kesehatan, 1(1), September 2013. Diakses 3September 2015 dari http://jurnal.unej.ac.id/index.php/JPK/article/view/500/371

Departemen Kesehatan Republik Indonesia. (2010). Pedoman Pelaksanaan Stimulasi, Deteksi dan Intervensi Dini Tumbuh Kembang Anak di Tingkat Pelayanan Kesehatan Dasar. Jakarta: Kemenkes RI

Departemen Pendidikan Nasional. (2006). Panduan Bimbingan di TK. Jakarta: Depdiknas

Desmita. (2011). Psikologi Perkembangan Peserta Didik. Bandung : PT. Remaja Rosda Karya

Goldstein, J. (2003). Contributions of Play and Toys to Child Development. Toy Industries of Europe

Hamalik, O. (2001). Proses Belajar Mengajar. Bandung: Bumi Aksara

Hamid, A. Y. S. (2008). Bunga Rampai Asuhan Keperawatan Kesehatan Jiwa. Jakarta: EGC

Harlock, E. B. (2007). Psikologi Perkembangan Suatu Pendekatan Sepanjang Rentang Kehidupan Edisi 5. (alih bahasa: Dra. Istiwidayanti \& Drs. Soedjarwo). Jakarta: PT. Erlangga

Hidayat, A. A. (2008). Pengantar Ilmu Kesehatan Anak untuk Pendidikan Kebidanan. Jakarta: Salemba Medika

Ikatan Dokter Anak Indonesia. (2013). Mengenal Keterlambatan Perkembangan Umum pada Anak. Diakses 3 September 2015 dari http://idai.or.id/artikel/seputarkesehatan-anak/mengenal-keterlambatan- perkembangan-umum-pada-anak

Irmawati, M., Ardani, I. G. A. I., Astasari, D., Irwanto., Suryawan, A., \& Narendra, MB. (2012). Pemberian Stimulasi Selama Satu Jam pada Perkembangan Anak Usia 12-24 Bulan. Media Medika Indonesia, 46(3), Tahun 2012. Semarang: M Med Indonesia. Diakses Diakses 3 September 2015 dari http://ejournal.undip.ac.id/index.php/mmi/article/view/4570/4162

Iswidharmanjaya, D., Svastiningrum, B., Sekarjati. (2008). Bila Anak Usia Dini Bersekolah; Panduan Bagi Orangtua untuk Menyiapkan Anak Usia Dini Menjelang Bersekolah. Jakarta: PT Elex Media Komputindo

Jafri, Y \& Isna, O. (2015). Hubungan Pemberian Stimulasi Sosialisasi dengan Perkembangan Sosialisasi pada Anak Prasekolah Umur 3-6 Tahun di Posyandu 
Kelurahan Pintu Kabun Kota Bukittinggi Tahun 2015. Diakses 19 Agustus 2015, dari http ://stikes perintis. ac.id/ifile/ Artikel\%20 Stimulasi\% 202015.pdf

Jamaris, M. D. (2006). Perkembangan dan Pengembangan Anak Usia Taman KanakKanak. Jakarta: Grasindo

Mahardikha. (2013). Permainan Edukatif dengan Menggunakan Media Puzzle Mengembangkan Kemampuan Kognitif Anak Usia 4-5 Tahun di TK Islamiyah. FKIP Untan

Mayar, F. (2013). Perkembangan Sosial Anak Usia Dini sebagai Bibit untuk Masa Depan Bangsa. Jurnal Al-Ta'lim, 1(6) 459-464

Mbae, M. (2011). Meningkatkan Kecerdasan Emosional Anak melalui Permainan Puzzle di TK Ikal Dolog Kecamatan Luwuk Kabupaten Banggai. Jurnal Pendidikan

Meadow, R \& Simon, N. (2005). Lecture Notes Pediatrika, Edisi ke Tujuh. Jakarta: Erlangga

Mulyasa. (2012). Manajemen Pendidikan Karakter. Jakarta : Bumi Aksara

Mustard, J. F. (2010). Early Brain Development and Human Development. Mustard JF, Editor. Encyclopedia on Early Childhood Development. Toronto: Centre of Excellent for Early Childhood Development

Novita, W. (2007). Serba-Serbi Anak; yang Perlu Diketahui Seputar Anak dari dalam Kandungan hingga Masa Sekolah (Tinjauan Psikologis dan Kedokteran). Jakarta: PT Elex Media Komputindo

Nugroho, H. S, W. (2009). Denver Developmental Screening Test: Petunjuk Praktis. Jakarta: EGC

Rahman, H. S. (2002). Konsep Dasar Pendidikan Anak Usia Dini. Yogyakarta: PGTKI Press

Rasyid, H. (2009). Asesmen Perkembangan Anak Usia Dini. Yogyakarta: Multi Pressindo

Sain, S. N. (2013). Pengaruh Alat Permainan Edukatif terhadap Aspek Perkembangan pada Anak Prasekolah di Wilayah Puskesmas Ondong Kabupaten Kepulauan Siau Tagulandang Biaro. Universitas Sam Ratulangi Manado Jurnal

Santrock, J. W. (2007). Perkembangan Anak. Terjemahan Mila rahmawati. Anna Kuswanti. Jakarta ID: Erlangga

Sari, L. P. (2007). Pengaruh Alat Permainan Edukatif terhadap Perkembangan Motorik Anak pada Taman Penitipan Anak. Tesis

Sari, L. P., Saing, B \& Lubis, I. Z. (2006). Hubungan antara Alat Permainan Edukatif dan Perkembangan Motorik Anak pada Taman Penitipan Anak. Majalah Kedokteran Nusantara 39(1)

Silawati, E. (2010). Teknik Stimulasi Guru pada Pembelajaran Berbicara dan Menulis Universitas Pendidikan Indonesia, PGPAUD. Diakses 19 Agustus 2015 dari http://a research.upi.edu/operator/upload/t_pd_0605029_chapter1.pdf

Soetjiningsih, C. H. (2012). Perkembangan Anak. Jakarta: Prenada Media Group

Sudaryanti. (2012). Pentingnya Pendidikan Karakter Bagi Anak Usia Dini. Jurnal Pendidikan Anak, 1(1), Juni 2012

Sukamti, E. (2007). Pengembangan Motorik. Yogyakarta: FIK UNY

Sunarti, E \& Rulli P. (2005). Ajarkan Anak Keterampilan Hidup Sejak Dini. Jakarta: Elex Media Komputindo

Supartini, Y. (2004). Buku Ajar Konsep Dasar Keperawatan Anak. Jakarta: EGC 
Susanty, A., Fadlyana, E., Nataprawira, H. M. (2014). Manfaat Intervensi Dini Anak Usia 6-12 Bulan dengan Kecurigaan Penyimpangan Perkembangan. Majalah Kedokteran Bandung (MKB), 46(2), Juni 2014. Diakses dari http://journal.fk.unpad.ac.id/index.php/mkb/article/view/275/pdf_131

Suyanto, S. (2005). Dasar-Dasar Pendidikan Anak Usia Dini. Yogyakarta: Hikayat Publishing

Wardhani, S. H. (2012). Terapi Bermain: Cooperative Play dengan Puzzle Meningkatkan Kemampuan Sosialisasi Anak Retradasi Mental. Journal Universitas Airlangga Surabaya

Wong, D. L. (2009). Buku Ajar Keperawatan Pediatrik ed. 6. Jakarta: EGC

Yahro, S. U. (2009). Upaya Guru dalam Mengembangkan Sosial-Emotional Anak Usia Dini dengan Pendekatan Beyond Centers and Circle Times (Kasus di TK Islam Modern Al-Furqon Yogyakarta). (Skripsi, tidak dipublikasikan). Fakultas Tarbiah UIN Sunan Kalijaga

Yamin dan Sabri (2013). Panduan Pendidikan Anak Usia Dini. Ciputat: Gaung Persada Press Group

Yulianty I, R. (2011). Permainan yang Meningkatkan Kecerdasan Anak. Jakarta: Laskar Aksara 